\title{
PENGEMBANGAN VIDEO MEDIA PEMBELAJARAN SENI RUPA TRADISIONAL DAYAK KALIMANTAN TENGAH BERBASIS VIRTUAL REALITY SMPN 2 PALANGKA RAYA
}

\author{
Iwan Pranoto ${ }^{*}$, Zuly Daima Ulfa ${ }^{2 *}$, Juli Natalia Silalahi ${ }^{3 *}$ Isna Herlina $^{4 *}$ Sagarli $^{\text {5* }}$ \\ Program Studi SENDRATASIK Jurusan Pendidikan Bahasa dan Seni ${ }^{1,4, \text { dan } 5^{*}}$ \\ Program Studi PJKR Jurusan Ilmu Keolahragaan dan Pendidikan Dasar ${ }^{2 *}$ \\ Fakultas Keguruan Ilmu Pendidikan \\ Program Studi Sosiologi Fakultas Ilmu Sosial dan Ilmu Politik ${ }^{3 *}$ \\ Universitas Palangka Raya \\ Jl. Yos Sudarso, Palangka Raya, Kode Pos 73111 \\ Kalimantan Tengah. Indonesia. \\ Email:pranotoiwan@fkip.upr.ac.id,zuly.daima@fkip.upr.ac.id, \\ julinataliasilalahi12@fisip.upr.ac.id,isnaherlina@gmail.com,sagarli@gmail.com
}

\begin{abstract}
Abstrak
Perkembangnya revolusi industri 4.0 memberikan dampak dalam pada perkembangan dunia pendidikan yang merupakan suatu tempat untuk mengembangkan serta menciptakan inovasi dalam berwawasan serta berkarakter dengan pemanfaatan seni dan teknologi, yaitu pengembangan pada karya seni tradisi berbasis virtual reality. Hal ini dilakukan guna pengayaan informasi pembelajaran seni budaya, serta menumbuhkan penanaman budaya lokal sebagai identitas bangsa. Pembelajaran dengan mengunakan virtual reality sangat mendukung dalam pembelajaran seni yang telah di kembangkan dalam video. Adapun rumusan masalah dalam penelitian ini yaitu bagaiman mengembangkan video media pembelajaran pada karya seni rupa tradisional suku Dayak di Kalimantan Tengah berbasis virtual reality di SMPN 2 Palangkaraya? Metode penelitian Research and Development $(R \& D)$ adalah metode penelitian yang digunakan untuk menghasilkan produk tertentu dan menguji keefektifan produk tersebut. Tahapan penelitian yaitu potensi dan masalah, proses pengumpulan data, desain produk, validasi desain, revisi desain, uji coba produk, revisi produk, produksi produk, analisis data. Dalam pengembangan video media pembelajaran seni rupa tradisional Dayak di Kalimantan Tengah berbasis virtual reality, bahwa produk media belajar dikembangkan berdasarkan kebutuhan kurikulum pendidikan yang di muat dalam perangkat mengajar apresiasi seni rupa daerah setempat, dengan muatan seni kerajinan, patung, arsitektur, keramik, senjata tradisional. Video yang dikembangkan akan di muat dalam durasi 10-15 menit berdasarkan jumlah pertemuan pembelajaran di SMPN 02 Palangka Raya, khsusnya pada siswa kelas VII. Pengembangan video media pembelajaran seni rupa ini di kemas dalam memadukan kemampuan teknologi virtual reality, sehingga proses belajar lebih menarik, dengan capaian aspek pendidikan yaitu sikap, pengetahuan dan keterampilan.
\end{abstract}

Kata Kunci: video, seni, virtual, reality, pendidikan.

\begin{abstract}
The development of the industrial revolution 4.0 has a profound impact on the development of the world education which is a place to develop and create innovations with insight and character by the use of art and technology, the development of virtual reality based traditional arts. This is done in order to enrich information on art and culture learning, as well as to foster the cultivation of local culture as a nation's identity. Learning by using virtual reality is very supportive in art learning that has been developed in the video. The formulation of the problem in this study is how to develop video learning media on traditional Dayak art works in Kalimantan Tengah based on virtual reality at SMPN 2 Palangkaraya?. Research and Development $(R \& D)$ research methods are research methods used to produce certain products and test the effectiveness of these products. The research stages are potential and problems, data collection process, product design, design validation, design revision, product testing, product revision, product production, data analysis. In the development of video learning media for traditional Dayak art in Kalimantan Tengah based on virtual reality, that learning media products are developed based on the needs of an educational curriculum that is contained in teaching tools for appreciation of local arts, with content in arts crafts, sculpture, architecture, ceramics, traditional weapons. . The developed video will be uploaded in 10-15 minutes based on the number of learning meetings at SMPN 02 Palangka Raya, especially for class VII students. The development of this visual art learning media video is packaged in combining the capabilities of virtual reality technology, so that
\end{abstract}


the learning process is more interesting, with the achievement of educational aspects, namely attitudes, knowledge and skills.

Keywords: video, art, virtual, reality, education.

\section{PENDAHULUAN}

Perkembangan industri 4.0 dalam duni pendidikan salah satunya yaitu pegembanagan media pembelajaran video berbasis virtual reality. Video merupakan suatu hasil dari penyajian yang dibuat untuk memperjelas proses pembelajaran dengan kekuatan audio visual. Seperti yang disampaikan oleh Trinawindu (2016:39) bahwa video dapat memperlihatkan keadaan yang sebenarnya dan dapat dilihat dengan cara berulangulang. Hal ini sangat mendukung suatu penyajian materi pembelajaran agar memperoleh hasil belajar yang kreatif serta inovatif, dengan penyajian virtual reality.

Virtual reality merupakan alat yang dikembangkan untuk menjadi fasilitas dalam penyajian produk-produk aplikasi salah satunya video, sehingga produk dunia maya akan terlihat seperti dunia nyata melalui video. Seperti yang disampaikan oleh Domingo (2018:330) bahwa virtual reality memberikan penyajian objek audio visual menjadi nyata. Dari pemaparan yang disampaikan bahwa virtual reality merupakan alat yang dapat mendukung proses belajar. Proses belajar ini dapat diterapkan dilingkungan sekolah SMPN 02 Palangkaraya. Hal itu bertujuan untuk meningkatkan konsentrasi pelajar sehingga memunculkan perhatian serta rasa kepemilikian terhadap karya seni rupa tradisi suku Dayak di Kalimantan Tengah, dengan memperhatikan aspek afektif, kognitif dan pisikomotorik.

Virtual reality merupakan alat yang dikembangkan untuk menjadi fasilitas dalam penyajian produk-produk aplikasi salah satunya video, sehingga produk dunia maya akan terlihat seperti dunia nyata melalui video. Seperti yang disampaikan oleh Domingo (2018:330) bahwa virtual reality memberikan penyajian objek audio visual menjadi nyata. Dari pemaparan yang disampaikan bahwa virtual reality merupakan alat yang dapat mendukung proses belajar. Proses belajar ini dapat diterapkan dilingkungan sekolah SMPN 02 Palangkaraya. Hal itu bertujuan untuk meningkatkan konsentrasi pelajar sehingga memunculkan perhatian serta rasa kepemilikian terhadap karya seni rupa tradisi suku Dayak di Kalimantan Tengah, dengan memperhatikan aspek afektif, kognitif dan pisikomotorik.

\section{KAJIAN TEORI}

\section{Pengembangan Media Pembelajaran Virtual Reality.}

Berkembangnya revolusi digital pada tahun 2000 an memberikan dampak bagi seluruh kehidupan manusia, sehingga disebut industri 4.0. Seperti halnya yang disampaikan oleh (Nusantara 2018:1) bahwa revolusi digital merupakan suatu system proliferasi komputer dan otomatisasi pencatatan di semua bidang. Industri 4.0. Dari pemaparan ini bahwa generasi digital ini akan memasuki semua system yang dibuat oleh manusia, salah satunya adalah pendidikan. Dalam lingkungan pendidikan mestinya memiliki pengembangan seiring berkembangnya teknologi, guna mencapai suatu tujuan keberhasilan dalam mendidik, salah satunya dengan adanya media pembelajaran yang dikemas semenarik mungkin dan mudah digunakan.

Dalam dunia pendidikan guna mencapai target pembelajaran dibuatlah kurikulum pendidikan, agar pendidik memiliki acuan serta capaian dalam mendidik. Seperti yang disampaikan oleh Fujiawati (2016:17) bahwa kurikulum dan pembelajaran merupakan bagian integral dari sistem pendidikan nasional, guna menjadikan pendidik yang professional. Dari pemaparan ini menjadi suatu acuan dalam melaksanakan pembelajaran yang berhasil, salah satunya dengan membuat inovasi. Seperti yang dismapaikan oleh Trinawindu (2016:36) bahwa proses pembelajaran merupakan kegiatan transfer ilmu dari pendidik kepada peserta didik dengan mengembangkan berbagai media dan inovasi”. Dari pendapat yang disampaikan bahwa kegiatan belajar mestinya memperhatikan perkembangan teknologi dengan berani berinovasi dalam mengembangkan media pembelajaran agar lebih menarik. Hal itu didasari dengan standar yang berkaitan dengan capaian pendidikan, meliputi kognitif, apektif dan pisikomotorik.

Media pembelajaran merupakan suatu bentuk dari pegembangan kreatifitas yang dilakukan pengajar kepada peserta didiknya, dengan cara mencari informasi serta pengembangan materi di dalam lingkungan pendidikan. Hal itu seperti yang disampaikan oleh Suhaya (2016:3) bahwa setiap pendidik dapat mengembangkan diri dengan melihat potensi peserta didik, guna mencapai suatu pembelajaran, proses pengembangan ini merupakan 
Gorga : Jurnal Seni Rupa

Volume 10 Nomor 02 Juli-Desember 2021

p-ISSN: 2301-5942 | e-ISSN: 2580-2380

munculnya kreatifitas. Dari pendapat yang disampaikan bahwa peran pendidik perlunya meningkatkan pengembangan dengan kreatif. Proses kreatif yang dilakukan merupakan kemampuan yang dihasilkan berupa produk atau gagasan apa saja yang pada dasarnya baru, dan sebelumnya tidak ada yang membuatnya, dengan konsep pengembangan.

Terdapat berbagai macam jenis mata pelajaran yang dikembangkan dalam pendidikan formal, sehingga setiap pendidik mesti harus mengembangkan diri sesuai dengan bidangnya masing-masing, salah satunya adalah mata pelajaran seni budaya, didalam pembelajaran seni sudah semestinya dapat dikembangkan dengan adanya media yang dikemas secara e-learning. Seperti yang disampaikan oleh Sofa (2020:2) bahwa dengan adanya pembelajaran elearning guru diberi kemudahan dalam menyiapkan konten pembelajaran yang meliputi aktifitas belajar yang kreatif dalam pembelajaran seni tari. Dari pendapat yang telah dikemukakan bahwa pembelajaran seni budaya memerlukan pengembangan melalui penyajian yang dimuat dalam sebuah media pembelajaran secara e-learning, salah satunya menggunakan video.

Hadirnya sebuah media pembelajaran berupa video di era revolusi 4.0 memberikan nuansa baru dalam pegembangan pembelajaran seni budaya, sehingga mempermudah akses belajar. Seperti yang disampaikan oleh Lase (2019:29) bahwa pendidikan 4.0 adalah respons terhadap kebutuhan revolusi industri 4.0 di mana manusia dan teknologi diselaraskan untuk menciptakan peluang-peluang baru dengan kreatif dan inovatif. Dari pemaparan ini menyatakan bahwa barang-barang elektronik merupakan alat yang dapat dikembangkan sebagai video sebagai media pembelajaran. Hal ini dapat dimuat dalam materi seni budaya khususnya seni rupa. Terdapat beberapa karya seni rupa di Indonesia yang menjadi suatu asset bangsa, salah satunya di Kalimantan. Seperti yang disampaikan oleh Pranoto (2020:106) bahwa terdapat piring keramik, guci, mangkuk berbahan keramik pada masyarakat Dayak di Kalimantan, dengan fungsi serta makna yang tersirat didalamnya. Dari pemaparan yang disampaikan bahwa karya seni rupa tradisi yang ada di Kalimantan dapat di muat dalam suatu pembelajaran apresiasi seni budaya, dengan penyajian video berbasis virtual reality.

Pengembangan video media pembelajaran yang dapat disajikan kepada peserta didik dalam aktifitas lansung maupun pembelajaran e-learnig, menggunakan berbagai macam jenis fasilitas elektronik serta aplikasinya. Seperti yang disampaikan oleh Setiaji (2020:15) bahwa berbagai aplikasi untuk berkarya seni kreatif seperti filpaclip, medibangpaint, procreate, sketchbook, artflow, infinite design serta adobe ilustrator yang dapat diakses menggunakan layar smartphone, guna mengembangkan diri melalui teknologi. Dari pemaparan diatas menyatakan bahwa dengan berkembangnya aplikasi era revolusi industri 4.0, video media pembelajaran dapat dikembangkan sesaui dengan kebutuhan materi pelajaran dan kemampuan dalam menggunakan alat pendukung salah satunya adalah virtual reality.

Di dalam pengembanagn video media pembelajaran berbasis virtual reality, memberikan kemudahan dalam pegembagan wawasan serta kualitas pendidikan, salah satunya pada mata pelajaran seni budaya. Seperti yang disampaikan oleh Dominggo (2018: 337) bahwa virtual reality memiliki kapasitas untuk meningkatkan kualitas pendidikan dengan membuka potensi pembelajaran lebih dari sebelumnya dan media ini sangat tepat di gunakan di Indonesia. Dari pemaparan yang disampiakan bahwa terdapatnya video media pembelajaran dengan menggunakan virtual reality merupakan bentuk dari pengembangan teknologi yang dapat di gunakan dalam kegiatan pembelajaran.

Berbagai macam aplikasi yang dapat di kembangkan dalam pengembanagn video media belajar berbasis virtual reality dapat didukung oleh fasilitas lainnya seperti smartphone, sebagai pengganti dari layar. Hal ini sepertiyang disampiakan oleh Retnanigsih (2019:29) bahwa perlunya kemampuan guru pembelajaran interaktif, pembuatan video pembelajaran guna mencapai pembelajaran yang mudah dipahami dan menarik serta tepat guna. Dari pemaparan yang disampiakan bahwa video media pembelajaran berbasis virtual reality, memberikan suatu tampilan baru bagi penikmat pembelajaran $e$ learning, diakrekan proses pembelajaran yang menyajikan dunia maya menjadi dunia nyata. Seperti yang disampaikan oleh Dominggo (2018:330) bahwa hampir $90 \%$ orang mampu mengingat informasi berdadsarkan apa yang dialami, misalnya dengan praktik langsung, aktifitas ini dapat dilakukan dengan teknologi virtual reality. Dari pemaparan yang disampaikan bahwa media pembelajaran dengan pengembangan aplikasi virtual reality sangat mendukung peserta didik dalam menumbuhkan pengalaman melalui perkembangan teknologi, sehingga dapat menggantikan pengalaman belajar secara langsung. 


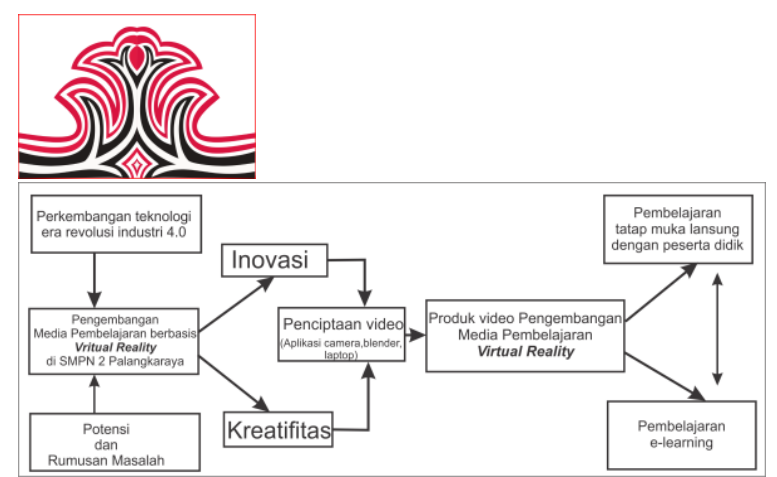

Gambar 1. Road Map Pengembangan Media Pembelajaran Virtual Reality di SMPN 2 Palangka Raya

\section{Media Pembelajaran pada Sekolah}

Pendidikan secara formal merupakan suatu aktifitas yang telah lama dikembangkan guna membentuk sumber daya manusia, sehingga di bentuknya kurikulum pendidikan. Seperti yang disampaikan oleh Ardipal (2010:2) bahwa kurikulum pendidikan memiliki peran dalam penyampaian proses belajar yang ada di sekolahformal. Dari pendapat yang dikemukakan bahwa kurikulum merupakan landasan dasar yang menjadi acuan guna mendukung proses belajar mengaja. Pendidikan secara formal dilakukan berdasarkan tingkatannya mulai dari sekolah dasar, menegah, atas dan perguruan tinggi, seperti yang disampaikan oleh Dewi (2016: 9) bahwa tingkatan pendidikan yang dilakukan secara formal meliputi Sekolah Dasar, Sekolah Menegah Pertama, Sekolah Menegah Atas dan kemudian dilanjutkan dengan tingkat Perguruan Tinggi.

Berdasarkan tingkatan pendidikan formal, tingkatan dan proses belajar yang berbeda-beda salah satunya adalah dalam pengajaran dan penerpan media pembelajaran. Seperti yang disampaikan oleh Ratnanigsih (2020:64) bahwa Proses komunikasi dapat berjalan dengan baik dibutuhkan media yang mengantarkan atau membawa informasi ke penerima informasi dalam melaksanakan pembelajaran. Dari pendapat yang disampaikan bahwa media memiliki peran dalam menjalin penyampaian materi pada peserta didik. Dalam pengembangan media pembelajaran yang dilakukan pada lingkungan sekolah memiliki karkater yang berbeda-beda, seperti yang disampaiakan oleh Hariyanto (2014:137) bahwa penggunaan media pembelajaran yang dilakukan untuk peserta didik tingkat Sekolah Dasar memerlukan pembuatan gambar karakter anak atau kartun, sedangkan untuk tingkat Sekolah Menegah Pertama hingga Sekolah Menegah Atas mesti menmperhatikan karakter gambar realis atau semi kartun, sedangkan untuk tingkat Pendidikan Tinggi menekankan pada gambar realis dan memiliki teks.

Berbagai macam jenis media pembelajaran yang dapat digunakan dalam proses penyampaian materi, baik secara digital dan peraga. Seperti yang disampaikan
Gorga : Jurnal Seni Rupa

Volume 10 Nomor 02 Juli-Desember 2021 p-ISSN: 2301-5942 | e-ISSN: 2580-2380

oleh Nurseto (2011: 23) bahwa media pembelajaran yang dapat digunakan dalam mencapai proses pembelajaran meliputi grafis, bahan cetak, gambar, proyeksi, audio,audio visual, visual. Dari pendapat yang dikemukakan bahwa media pembelajaran yang gunakan dalam proses belajar memiliki bentuk dan bagian berdasarkan fungsinya. Berdasarkan perkembangannya Kata "Media" berasal dari bahasa latin yang merupakan bentuk jamak dari "medium", secara harfiah berarti perantara atau pengantar, seperti yang disampaikan oleh Hariyanto (2014: 136) bahwa media memiliki peran sebagai perantara antara peserta didik dengan pendidik.

Dalam pembuatan media pembelajaran yang dilakukan mesti memperhatikan aspek audio visual, seperti yang disampaikan oleh Ratnanigsih (2020:66) bahwa dalam pengembagan media pembelajaran mesti menekankan kejelasan pada audio, gambar dan tipografi dengan memperhatikan komposisi pada setiap bagian media yang dibuat. Dari pendapat yang dikemukakan bahwa pembuatan media pembelajaran memiliki kekuatan pada audio, gambar, dan tipografi, sehingga proses belajar yang disampaikan dapat dipahami oleh peserta didik, baik itu isi materi serta dapat menigkatkan pengalaman dalam belajar.

Pembuatan audio pada media pembelajaran mesti memperhatikan proses rekam dan editor pada saat membuat media pembelajaran. Seperti yang disampaikan oleh Suryani (2021: 905) bahwa proses pembuatan audio pada media belajar digunakan dengan cara merekam, dan memperhatikan suara yang ada disekitar proses rekam agar memiliki kualitas audio yang baik. Berdasarkan pendapat yang dikemukan bahwa dalam melakukan proses rekam audio sebaiknya dilakukan di tempat yang sepi dan jauh dari keramaian. Hal itu memiliki tujuan agar audio yang di rekam memiliki suara jernih dan dapat di dengarkan dengan jelas pada saat penggunanya.

Dalam pembuatan media pembelajaran khususnya gambar sebagai sumber informasi secara visual, mesti memperhatikan konsep estetik, sehingga dapat di pahami dan memiliki ketercapain dalam menyampaikan isi dari pembelajaran. Seperti yang disampaikan oleh Darihastining (2021:1595) bahwa penggunaan gambar pada media belajar mesti memperhatikan komposisi, warna, karakter dan keseuaian tema". Dari pendapat yang dikemukakan bahwa bagian unsur visual merupakan peranan penting guna mencapai media pembelajaran visual yang baik. Hal ini mendasari proses pembuatan media belajar yang efektif secara kreatif dan inovatif. 
Gorga : Jurnal Seni Rupa

Volume 10 Nomor 02 Juli-Desember 2021

p-ISSN: 2301-5942 | e-ISSN: 2580-2380

Audio visual yang dikembangkan sebagai dasar dalam membuat media pembelajaran. Hal itu tidak lepas pada kreatifitas yang dimiliki oleh pendidik dalam menyampaikan materi ajar. Seperti yang disampaikan oleh Harianto (2014: 138) bahwa proses pengajaran yang dilakukan mesti kreatif dalam pembuatan media pembelajaran, dengan menekankan kekuatan audio visual. Dari pendapat yang telah dikemukakan bahwa media pembelajaran dengan konsep audio visual dapat di jumpai pada media belajar video, dan audio. Ketepatan yang diutamakan pada media ini meliputi indra penglihatan dan pendegaran, sehingga dengan adanya media belajar ini dapat membatu proses pemahaman materi.

Media video merupakan suatu sumber informasi belajar yang dapat dipahami dengan pemanfaatan teknologi. Hal ini tidak lepas dari sarana dan prasarana belajar yang mendukung, seperti HP, TV, Laptop, Komputer sebagai alat pendukung dalam pengoprasiannya. Seperti yang disampaikan oleh Harianto (2014133) bahwa media video yang digunakan dalam proses belajar dapat di oprasionalkan menggunakan barangbarang elektronik. Dari pendapat yang dikemukakan bahwa di era digital ini barang-barang elektronik sudah di miliki oleh sebagian besar lengkungan pendidikan formal khsusnya pendidikan yang ada di kota besar.

Pembuatan media pembelajaran yang dilakukan guna mencapai suatu proses belajar dapat dilakukan secara digital. Hal ini tidak lepas dari perkembangan teknologi dan sumber daya manusia yang telah mengenal teknologi pendukung. Seperti yang disampaikan oleh Asikin (2019: 73) bahwa perkembagan teknologi dalam dunia pendidikan membuat guru dapat membuat media belajar seperti video, poster. Dari pendapat yang dikemukan bahwa dalam proses pembuatan media pembelajaran khususnya video sangat efektif dan memungkinkan di ciptakan oleh pendidik. Hal itu selain adanya barang-barang elektronik dan pendidik di era digital ini memiliki kreatifitas yang tinggi dalam mengembangkan media ajar.

\section{METODE PENELITIAN}

\section{Metode Penelitian Research and Development}

Metode penelitian Research and Development (R\&D) adalah metode penelitian yang digunakan untuk menghasilkan produk tertentu dan menguji keefektifan produk tersebut. Seperti yang disampaikan oleh Sugiyono (2011 :297) bahwa produk yang dihasilakn peneliti bersifat analisis kebutuhan guna menguji keefektifan produk supaya dapat berfungsi di masyarakat luas, maka diperlukan penelitian untuk menguji keefektifan produk. Dalam penelitian ini menghasilkan produk video media pembelakaran berbasis virtual reality.

\section{Langkah- Langkah Penelitian}

Langkah - langkah dalam penelitian dan pengembangan menurut Sugiyono (2011 :298) prosedur pengembangan produk adalah, potensi dan masalah, pengumpulan data, desain produk, validasi desain,revisi desain, uji coba produk, revisi produk, uji coba pemakaian, revisi produk, produksi masal. Dari pendapat yang dikemukakan peneliti megadaptasi delapan cara dari 10. Berikut ini tahapan penelitian pengembangan produk berupa video media pembelajaran berbasis virtual reality, yang akan disajikan dalam bentuk gambar berikut ini;

\section{1). Potensi dan Masalah}

Penelitian ini berangkat dari adanya potensi dan masalah dalam pegembangan media pembelajaran. Penelitian serupa pernah dilakukan di Universitas Pendidikan Indonesia dengan membuat video galeri seni untuk pameran karya seni rupa, yang dapat tayangkan melalui smartphone. Penelitian ini kemudian dikembangkan menjadi media pembelajaran yang dikemas dalam video berbasis virtual reality, dengan isi materi seni rupa tradisi suku Dayak di Kalimantan Tengah.

\section{2). Proses Pengumpulan Data}

Proses pengumpulan informasi dilakukan secara faktual dan dapat digunakan sebagai bahan untuk perencanaan produk tertentu yang diharapkan dapat mengatasi masalah pengembangan video media pembelajaran berbasis virtual reality. Tahap awal pencarian informasi didapat dari teori-teori yang berhubungan dengan pengembangan video, media pembelajaran dan virtual reality. Pustaka yang digunakan yaitu berupa buku-buku teks yang berupa tulisan ilmiah, handbook, e-book, buku reverensi

\section{3). Desain Produk}

Desain produk atau model pengembangan yang dihasilkan adalah sebagai berikut ini;

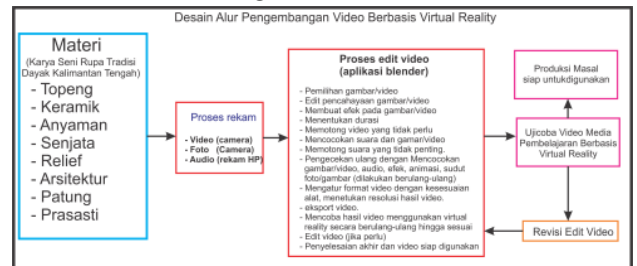

Gambar 2. Desain pengembangan Video Pembelajaran Berbasis Visaul Reality 
Gorga : Jurnal Seni Rupa

Volume 10 Nomor 02 Juli-Desember 2021

p-ISSN: 2301-5942 | e-ISSN: 2580-2380

\section{4). Validasi Desain}

Validasi desain merupakan proses kegiatan pengecekan rangcangan produk lebih efektif atau tidak, dengan melibatkan pakar dalam bidang penelitian yaitu dosen di bidang desain komunikasi visual dan seni rupa, serta pakar dibidang pendidikan dan media pembelajaran. Berikut ini tahapan yang perlu diperhatikan dalam melakukan valiadsi produk:

Tabel:1. Indikator valiadsi pada produk desain (Zunaidah, 2016:21)

\begin{tabular}{|c|c|}
\hline Komponen validasi & Indikator \\
\hline Cakupan materi & $\begin{array}{l}\text { a. Pendahuluan } \\
\text { b. Kesesuaian tema pembelajaran } \\
\text { c. Model video } \\
\text { pembelajaranberbasis Virtual } \\
\text { Reality } \\
\text { d. Isi dari video media } \\
\text { pembelajaran berbasis virtual } \\
\text { reality. }\end{array}$ \\
\hline Indikator dan tujuan & $\begin{array}{l}\text { a. Kesesuaian Kurikulum } 2013 \\
\text { b. Kesesuaian silabus/RPP } \\
\text { c. Kesesuaian Durasi Video. } \\
\text { d. Kesesuaian penggunaan Virtual } \\
\text { Reality. } \\
\text { e. Keseuaian Perangkat Mengajar } \\
\quad \text { dan bahan ajar. }\end{array}$ \\
\hline $\begin{array}{l}\text { Proses/kegiatan } \\
\text { pembelajaran }\end{array}$ & $\begin{array}{l}\text { a. Kesesuaian isi gambar dan } \\
\text { video. } \\
\text { b. Kesesuaian audio visual. } \\
\text { c. Penyampaian pembelajaran } \\
\text { menjadi jelas. } \\
\text { d. Pengaruh terhadap sikap } \\
\text { e. Pengaruh terhadap pengetahuan } \\
\text { f. Pengaruh pada keterampilan } \\
\text { g. Strategi pembelajaran yang } \\
\text { digunakan sesuai. } \\
\text { h. Proses evaluasi pembelajaran } \\
\text { dapat dilaksanakan. }\end{array}$ \\
\hline $\begin{array}{l}\text { Penyajian } \\
\text { pembelajaran }\end{array}$ & $\begin{array}{l}\text { a. Kesesuaian materi seni rupa } \\
\text { tradisional suku Dayak } \\
\text { Kalimantan Tengah. } \\
\text { b. Kesesuaian video media } \\
\text { pembelajaran seni rupa } \\
\text { tradisional suku Dayak, berbasis } \\
\text { virtual reality. } \\
\text { c. Kesesuaian evaluasi } \\
\text { pembelajaran seni rupa } \\
\text { tradisional suku Dayak di } \\
\text { Kalimantan Tengah. }\end{array}$ \\
\hline Penyajian & $\begin{array}{l}\text { a. Umpan balik untuk peneliti } \\
\text { b. Konsistensi pengembangan } \\
\text { video media pembelajaran } \\
\text { berbasis virtual reality. } \\
\text { c. Karya yang dihasilkan } \\
\text { merupakan karya orisinil (bukan } \\
\text { plagiat) }\end{array}$ \\
\hline Kebahasaan & $\begin{array}{l}\text { a. Kemampuan menginspirasi } \\
\text { Peneliti. } \\
\text { b. Dapat membuat peneliti untuk } \\
\text { berpikir kreatif. } \\
\text { c. Kebakuan penggunaan istilah } \\
\text { pada video media pembelajaran } \\
\text { seni rupa tradisional Dayak, } \\
\text { berbasis virtual reality. } \\
\text { d. Penjelasan dengan pemaknaan } \\
\text { dalam setiap penyajian pada } \\
\text { video media pembelajaran karya } \\
\text { seni rupa tradisional Dayak, } \\
\text { berbasis virtual reality. }\end{array}$ \\
\hline
\end{tabular}

e. Keterhubungan isi materi dengan video media pembelajaran seni rupa tradisional suku Dayak, berbasis virtual reality

f. Kebakuan penggunan bahasa pada video media pembelajaran seni rupa tradisional Dayak berbasis virtual reality.

\begin{tabular}{l|l} 
Penerapan dan & a. Pengembangan video media \\
pembelajaran pada karya seni & rupa tradisional suku Dayak di \\
& Kalimantan Tengah berbasis \\
& virtual reality di SMPN 2 \\
& Palangkaraya. \\
b. Pengembangan video media & pembelajaran pada karya seni \\
rupa tradisional suku Dayak di & Kalimantan Tengah berbasis \\
virtual reality di SMPN 2 & Palangkaraya
\end{tabular}

Dalam proses pengolahan data pada bagian validasi yang dilakukan oleh para ahli di bidang desain dan pengembangan media pembelajaran seni, maka diperlukannya statistik, seperti yang disampaikan oleh Zunaidah (2016:21) yaitu diperlukan pengolahan data dari hasil validasi ahli materi yang kemudian dapat di analisis statistik deskriptif kualitatif dalam bentuk analisis presentase dengan kriteria penilaian 81-100 dinyatakan sangat baik, 61-80 diyatakan baik, 41-60 diyatakan cukup, 21-40 diyatakan kurang, dan 0-20 diyatakan sangat kurang . Berdasarkan pendapat yang dikemukakan bahwa diperlukan perhitungan untuk menerangkan sistematis validasi produk. Lembar validasi pada produk dapat dibuat dalam bentuk deskripsi kualitatif dengan kategori sangat baik, baik, cuku, kurang, sangat kurang adapun rumus yang digunakan yaitu:

$$
\begin{aligned}
& P=\frac{\left.\sum \text { (seluruh skor jwb angket }\right)}{n x \text { terting gi } x \text { jml responden }} \times 100 \% \\
& \text { Keterangan: } \\
& \mathrm{P}=\text { menyatakan persentase penilaian } \\
& \mathrm{n}=\text { menyatakan jumlah seluruh item angket }
\end{aligned}
$$

Gambar 3. Rumus menghitung persentasi validasi produk (Zunaidah, 2016:22)

\section{5). Revisi Desain}

Setelah menghasilkan berbagai masukan dan kelemahan dari rangcangan. Dari hasil inilah kemudian akan dilakukan beberapa perubahan yang menjadikan hasil pengembangan menjadi berkualitas. Jika tidak terdapat revisi maka peneliti melanjutkan ke langkah penelitian yang selanjutnya.

\section{6). Uji Coba Produk}

Tahap selanjutnya akan dilakukan uji coba produk. Uji coba produk ini bisa dilakukan beberapa kali sesuai dengan kebutuhan analisis. 


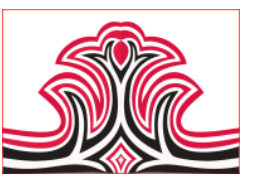

7). Revisi Produk

Tahapan selanjutnya adalah revisi produk berdasarkan masukan dan saran Jika tidak terdapat revisi maka peneliti melanjutkan ke langkah penelitian yang selanjutnya.

\section{8). Produksi Produk}

Produk sudah dianggahapan selesai dengan hasil yang produk sudah siap di produksi dan digunakan.

\section{HASIL DAN PEMBAHASAN}

1.Hasil

\section{1). Proses Pengambilan Gambar dan Video}

Pengembangan media pembelajaran video media pembelajaran seni budaya, khususnya pada materi seni rupa tradisional masyarakat Dayak yang ada di Kalimantan Tengah, berbasis virtual reality, yaitu meliputi proses pengambilan gambar atau video, yang berkaitan dengan koleksi karya seni rupa tradisional suku Dayak, meliputi Arsitektur, ragam hias, kerajinan, keramik, senjata, patung. Objek karya seni rupa tradisional yang di rekam secara visual dan audio visual merupakan benda sakral dan benda terapan.

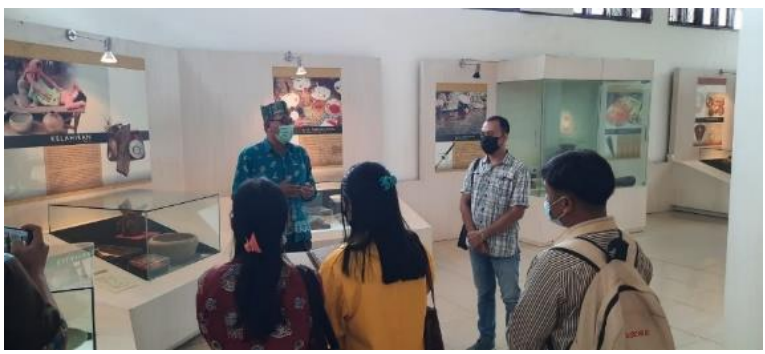

Gambar 4. Proses Merekam Karya Seni Rupa (Pranoto, 2020)

Proses pengambilan gambar dan video meliputi beberapa daerah yaitu Kabupaten. Katingan, Kabupaten. Gunung Mas, Kabupaten Barito Selatan dan Kota Palangka Raya, dengan tahapan dan waktu yang berbeda-beda. Dalam proses pengambilan gambar dan video guna keperluan pembuatan media video pembelajaran seni rupa, menggunakan kamera $\mathrm{Hp}$ android dan kamera DSLR, dengan memperhatikan komposisi serta konsep visual secara estetik, agar mencapai tujuan hasil yang dianggap lebih baik dan sesuai. Hal itu memiliki tujuan agar gambar dan video lebih jelas dan tidak banyak yang akan direduksi, sehingga lebih mudah dalam proses editing video media pembelajaran.
Gorga : Jurnal Seni Rupa

Volume 10 Nomor 02 Juli-Desember 2021 p-ISSN: 2301-5942 | e-ISSN: 2580-2380

Tabel 2. Video dan Gambar Yang Akan di Gunakan Untuk Pembelajaran Apresiasi Karya Seni Rupa di SMPN 02 Palangka Raya

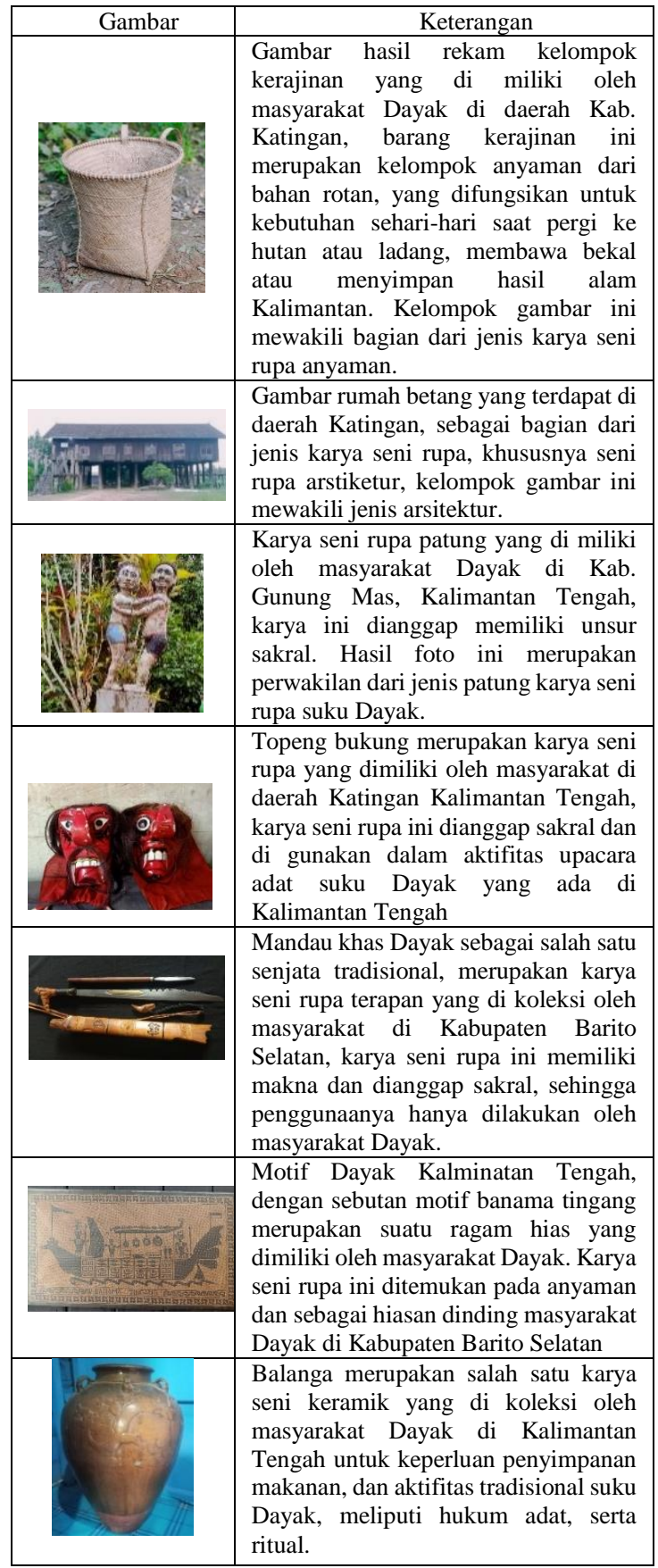

Dari jenis gambar yang telah yang telah disampaikan, bahwa karya seni rupa masyarakat Dayak yang ada di Kalimantan Tengah memiliki bentuk dan fungsi yang berbeda-beda, sehingga karya seni rupa yang di dokumentasikan secara lebih banyak, guna untuk pengayaan dokumen visual, kemudian nantinya akan dilakukan proses reduksi.

\section{2). Proses Reduksi Gambar dan Video}

Dalam pembuatan video media pembelajaran berbasis virtual reality pada mata pelajaran seni rupa tradisional 
suku Dayak, memerlukan data-data yang sesuai dengan konsep pembelajaran seni rupa berdasarkan kurikulum pendidikan yang ada di SMPN 02 Palangka Raya, sehingga perlunya reduksi terhadap foto dan video yang nantinya akan di gunakan dalam membuat video. Dalam proses reduksi video ini dilakukan secara cermat dan pengelompokan berdasarkan keperwakilan dari jenis kelompok karya seni rupa tradisional suku Dayak Kalimantan Tenggah.

\section{3). Proses Penyesuai Tema Belajar}

Setelah melaksanakan proses reduksi pada gambar dan video, maka tahapan selanjutnya adalah menyesuaikan isi materi berdasarkan indikator pembelajaran yang dilakukan oleh guru mata pelajaran seni budaya, khususnya materi seni rupa. Dalam tahapan ini video media pembelajaran dapat di kelompokan dan menentukan durasi dari isi video. Hal ini dilakukan agar proses penyampaian materi yang dilakukan oleh guru sesuai dengan pembagian waktu pembelajaran di kelas. Berdasarkan pengelompokan yang dilakukan berikut ini terdapat karya seni rupa arsitektur berupa rumah betang, dan sanding, kelompok ragam hias berupa motif-motif yang ada pada anyaman, senjata, balanga dan sanding. Karya seni rupa kelompok patung meliputi sampundu, karya tradisional kelompok senjata Mandau, dan karya kelompok topeng yaitu bukung, kelompok anyaman, kelompok keramik yaitu belanga.

Dalam proses penyesuaian tema belajar ini kemudian di bagi dalam jumlah pertemuan kelas, sehingga setiap kelompok akan di sampaikan pada setiap pertemuan, hingga proses pembelajaran sei rupa dapat tercapai, dalam mengapresiasi seni rupa tradisional suku Dayak yang ada di Kalimantan Tengah. Setelah proses penyesuaian tema, maka tahapan selanjutnya adalah proses editing berdasarkan kelompok dokumen gambar, foto dan video.

\section{4). Proses Edit}

Tahapan yang dilakukan dalam melaksanakan proses editing video diperlukannya data-data berupa foto atau video. Setiap bagian dari foto dan video yang akan digunakan sudah melewati tahapan reduksi, dan merupakan foto dan video yang telah terpilih dan memenuhi kriteria kejelasan secara audio visual. Pembuatan video ini menggunakan HP android yaitu aplikasi VN. Beriku ini tahapan yang dilakukan proses editing video media pembelajaran berbasis virtual reality di SMPN 02 Palangka Raya, pada mata pelajaran seni rupa tradisional masyarakat Dayak yang ada di Kalimantan Tengah.
Gorga : Jurnal Seni Rupa

Volume 10 Nomor 02 Juli-Desember 2021 p-ISSN: 2301-5942 | e-ISSN: 2580-2380

\section{5). Proses Ujicoba Audio Visual}

Kegiatan pembelajaran seni budaya, khususnya pada materi apresiasi karya seni rupa dapat dilakukan dengan pengembangan video media pembelajaran berbasis virtual reality. Dalam penerapan pembelajaran apresiasi pada karya seni rupa tradisional yang ada pada suku Dayak di Kalimantan Tengah ini meliputi beberapa bagian, yaitu seni anyaman, aksesoris, patung, arsitektur, ragam hias, dan senjata tradisional. Proses penerpan media pembelajaran ini dilakukan pada tingkatan pendidikan formal yang ada di Palangka Raya yaitu, SMPN 02 Palangka Raya.

Dalam tahapan uji coba yang dilakukan dapat menyesuaikan dengan isi dari Rencana Pelaksanaan Pembelajaran di Sekolah yang dilakukan oleh guru mata pelajaran, meliputi indikator pembelajaran berdasarkan kurukulum pendidikan. Media pembelajaran ini akan dilakukan tahapan uji coba, agar dapat di gunakan kepada peserta didik, dengan meliputi audio visual, keseusian tema, ketercapaian pembelajaran. Berikut ini tahapan uji coba yang dilakukan oleh beberapa guru di lingkungan SMPN 02 Palangka Raya, Mahasiswa Seni, Dosen, Praktisi di bidang seni dan media.

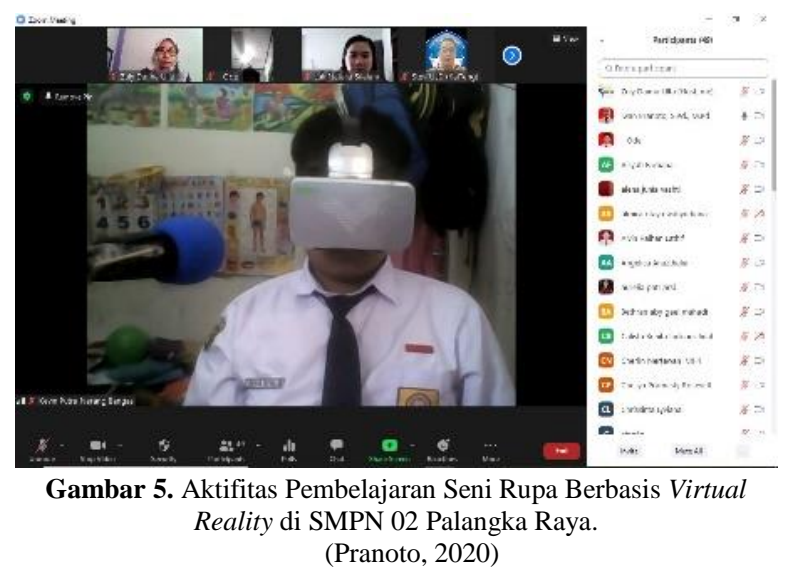

Berdasarkan hasil uji coba produk video media pembelajaran seni rupa tradisional berbasis virtual reality, yang dilakukan di lingkungan SMPN 02 Palangka Raya, bahwa media yang di buat dapat di gunakan dan di produksi secara masal. Hal itu di buktikan dengan adanya pertimbangan-pertimbangan khusus, baik dari isi materi, kurikulum pendidikan, sumber belajar dan adanya respon secara positif terhadap produk video media pembelajaran berbasis teknologi virtual reality. 
2. Pembahasan

1). Pengembangan Video Media Pembelajaran pada Karya Seni Rupa Tradisional Suku Dayak di Kalimantan Tengah Berbasis Virtual Reality di SMPN 2 Palangkaraya

Pengembangan pendidikan seni budaya yang meliputi seni rupa, tari, musik, drama, dan desain, di muat dalam suatu aktifitas belajar. Hal ini di lakukan oleh guru seni budaya yang ada di SMPN 02 Palangka Raya, khususnya di bidang seni rupa. Berbagai macam pembelajaran seni rupa yang di muat guna mencapai tujuan kurikulum pendidikan, salah satunya adalah belajar tentang seni rupa tradisi yang dimiliki oleh masyarakat Dayak yang ada di Kalimantan Tengah. Karya seni rupa yang disajikan dalam pembelajaran meliputi dengan adanya acuan rencana pelaksanaan pembelajaran yang berkaitan dengan nilai-nilai budaya setempat. Adapun karya seni rupa tradisi suku Dayak Kalimantan Tengah yang di muat dalam materi pembelajaran seni budaya yaitu, patung, kerajinan anyaman, benda-benda keramik, arsitektur, topeng, dan ragam hias

Pembelajaran seni rupa yang dilakuka oleh guru perlunya inovasi pengembangan media belajar, salah satunya adalah membuat video media pembelajaran, berbasis virtual reality. Video merupakan suatu hasil rekam baik itu berupa gambar dan visual gerak yang memiliki kekuatan penyampaian pada audio vsual, sedangkan virtual reality merupakan alat yang digunakan untuk mencapai suatu pembelajaran agar proses belajar lebih menarik. Sehingga dapat menumbuhkan rasa percaya diri dalam mengapresiasi video media pembelajaran seni rupa berbasis virtual reality, berikut ini gambar tampilan video media pembelajaran yang di kembangkan, berbasis virtual reality.

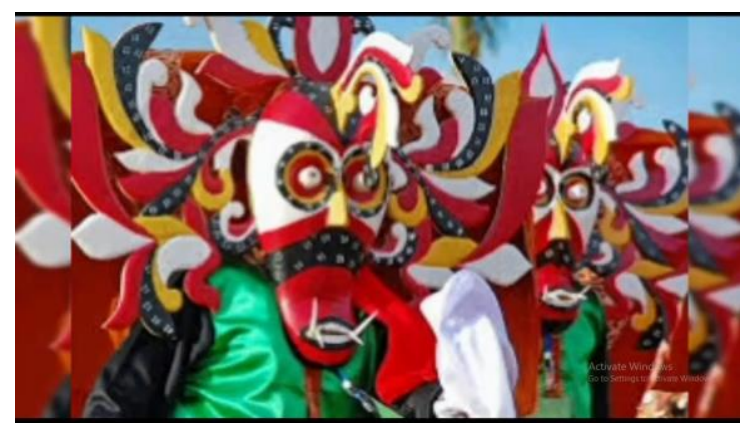

Gambar 6. Tampilan Video Pembelajaran Seni Rupa Berbasis Virtual Reality di SMPN 02 Palangka Raya. (Pranoto, 2020)

2). Kelayakan dan Ketercapaian Pengembangan Video Media Pembelajaran pada Karya Seni Rupa Tradisional Suku Dayak di Kalimantan Tengah Berbasis Virtual Reality di SMPN 2 Palangkaraya
Pengembangan video media pembelajaran pada karya seni rupa tradisional suku Dayak di Kalimantan Tengah berbasis virtual reality yang di kembangkan untuk pembelajaran seni budaya di lingkungan SMPN 02 Palangka Raya, dapat di gunakan secara efektif. Hal itu dikarenakan perlunya media pembelajaran guna mendukung indikator pembelajaran yang termuat dalam kurikulum pendidikan, sehingga produk yang di buat dapat bermanfaat dan tepat guna. Dalam pencapaian dan kelayakan produk video media pembelajaran berbasis virtual reality, dibuktikan dengan adanya validasi yang dilakukan oleh ahli di bidang media pembelajaran, terdiri dari dosen, dinas taman budaya Kalimantan Tengah, beriku ini rincian hasil validasi terhadap produk video media pembelajaran seni rupa tradisional suku Dayak di Kalimantan Tengah berbasis virtual reality di SMPN 02 Palangka Raya.

Tabel 3. Persentasi Hasil Validasi Cakupan Materi pada Produk Video Media Pembelajaran Seni Rupa Tradisional Suku Dayak di Kalimantan Tengah Berbasis Virtual Reality di SMPN 02 Palangka Raya

(Zunaidah, 2016:23)

\begin{tabular}{|c|c|c|c|c|c|}
\hline \multirow[t]{2}{*}{ No } & $\begin{array}{c}\text { Aspek } \\
\text { Validasi }\end{array}$ & \multirow{2}{*}{$\begin{array}{c}\begin{array}{c}\text { Score } \\
\text { total }\end{array} \\
\text { untuk } \\
3 \\
\text { Respo } \\
\text { nden } \\
\end{array}$} & \multirow{2}{*}{$\begin{array}{c}\text { Skor } \\
\text { max } \\
\text { untuk } 3 \\
\text { Respon } \\
\text { den }\end{array}$} & \multirow[t]{2}{*}{$\%$} & \multirow{2}{*}{$\begin{array}{c}\text { Kriteri } \\
\text { a } \\
\text { penilai } \\
\text { an } \\
\text { produ } \\
\text { k } \\
\end{array}$} \\
\hline & $\begin{array}{c}\text { Cakupan } \\
\text { Materi }\end{array}$ & & & & \\
\hline 1 & $\begin{array}{l}\text { Pendahulua } \\
\mathrm{n}\end{array}$ & 11 & 12 & 91,6 & $\begin{array}{c}\text { Sangat } \\
\text { baik }\end{array}$ \\
\hline 2 & $\begin{array}{l}\text { Kesesuaian } \\
\text { tema } \\
\text { pembelajar } \\
\text { an }\end{array}$ & 11 & 12 & 91,6 & $\begin{array}{c}\text { Sangat } \\
\text { Baik }\end{array}$ \\
\hline 3 & $\begin{array}{l}\text { Model } \\
\text { video } \\
\text { pembelajar } \\
\text { an berbasis } \\
\text { Virtual } \\
\text { Reality } \\
\end{array}$ & 12 & 12 & 100 & $\begin{array}{c}\text { Sangat } \\
\text { Baik }\end{array}$ \\
\hline 4 & $\begin{array}{l}\text { Kesesuaian } \\
\text { Video } \\
\text { Pembelajar } \\
\text { an berbasis } \\
\text { Virtual } \\
\text { reality. }\end{array}$ & 11 & 12 & 91,6 & $\begin{array}{c}\text { Sangat } \\
\text { Baik }\end{array}$ \\
\hline 5 & $\begin{array}{l}\text { Isi dari } \\
\text { video } \\
\text { media } \\
\text { pembelajar } \\
\text { an berbasis } \\
\text { virtual } \\
\text { reality. }\end{array}$ & 11 & 12 & 91,6 & $\begin{array}{c}\text { Sangat } \\
\text { Baik }\end{array}$ \\
\hline
\end{tabular}

Hasil perhitungan seruh cakupan materi dengan kelayakan penilaian validasi dapat diyatakan sangat baik dan layak digunakan,meliputi pendahuluan, keseuaian tema pembelajaran, model video pembelajaran berbasis virual reality, kesesuaian video media pembelajaran berbasis virtual reality, isi dari video media pembelajaran berbasis virtual reality. Hal penilaian yang menjadi acuan dapat dicocokan dengan 


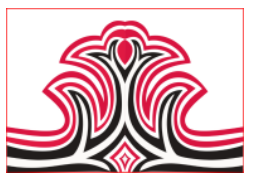

indikator penilaian kelayakan produk yang meliput cakupan materi pendahuluan dengan score total dari 3 responden yaitu 11 dan skore maxsimal 12, dengan persentasi 91,6 \%, kriteria penilaian produk sangat baik.

Aspek validasi yang memuatkan tema pembelajaran dengan score total 11 dan score maxsimal 12, dengan persentasi 91,6 \% dan dinyatakan sangat baik, sedangkan aspek model video pembelajaran berbasis virtual reality score totalnya 12 dan score maxsimal 12 dengan persentasi $100 \%$, diyatakan sangat baik. Kesesuaian video pembelajaran berbasis virtual reality dengan score total 11, score maxsimal 12 dengan persentasi $91,6 \%$ dinyatakan sangat baik, sedangkan isi dari video media pembelajaran berbasis virtual reality, dengan score total 11, score maxsimal 12, dengan persentasi 91,6\%, diyatakan Sangat Baik. Berdasarkan penilaian yang dilakukan validator dapat di simpulkan bahwa aspek validasi yang berkaitan dengan cakupan materi sangat baik dan layak untuk di gunakan dalam pengembangan video media pembelajaran seni rupa tradisional di Kalimantan Tengah berbasis virtual reality di lingkungan SMPN 02 Palangka Raya.

Tabel 4. Persentasi Hasil Validasi Indikator dan Tujuan pada Produk Video Media Pembelajaran Seni Rupa Tradisional Suku Dayak di Kalimantan Tengah Berbasis Virtual Reality di SMPN 02 Palangka Raya (Zunaidah, 2016:23)

\begin{tabular}{|c|c|c|c|c|c|}
\hline No & $\begin{array}{c}\text { Aspek } \\
\text { Validasi } \\
\text { Indikator } \\
\text { dan } \\
\text { Tujuan }\end{array}$ & $\begin{array}{c}\text { Score } \\
\text { total } \\
\text { untuk } 3 \\
\text { Respon } \\
\text { den }\end{array}$ & $\begin{array}{c}\text { Sko } \\
\mathbf{r} \\
\text { max } \\
\text { untu } \\
\mathbf{k} 3 \\
\text { Res } \\
\text { pon } \\
\text { den }\end{array}$ & $\%$ & $\begin{array}{c}\text { Kriteria } \\
\text { penilaia } \\
\mathbf{n} \\
\text { produk }\end{array}$ \\
\hline 1 & $\begin{array}{l}\text { Kesesuaian } \\
\text { Kurikulum } \\
2013\end{array}$ & 11 & 12 & 91,6 & $\begin{array}{c}\text { Sangat } \\
\text { Baik }\end{array}$ \\
\hline 2 & $\begin{array}{l}\text { Kesesuaian } \\
\text { Silabus/RP } \\
\mathrm{P}\end{array}$ & 12 & 12 & 100 & $\begin{array}{c}\text { Sangat } \\
\text { Baik }\end{array}$ \\
\hline 3 & $\begin{array}{l}\text { Kesesuaian } \\
\text { Durasi } \\
\text { Video. }\end{array}$ & 10 & 12 & 83,3 & $\begin{array}{c}\text { Sangat } \\
\text { Baik }\end{array}$ \\
\hline 4 & $\begin{array}{l}\text { Kesesuaian } \\
\text { penggunaan } \\
\text { Virtual } \\
\text { Reality. }\end{array}$ & 12 & 12 & 100 & $\begin{array}{c}\text { Sangat } \\
\text { Baik }\end{array}$ \\
\hline 5 & $\begin{array}{l}\text { Keseuaian } \\
\text { Perangkat } \\
\text { Mengajar } \\
\text { dan bahan } \\
\text { ajar. }\end{array}$ & 11 & 12 & 91,6 & $\begin{array}{c}\text { Sangat } \\
\text { Baik }\end{array}$ \\
\hline
\end{tabular}

Dari hasil penilaian yang dilakukan oleh validator, maka dapat disimpulkan bahwa indikator dan tujuan yang meliputi aspek kurikulum, silabus,RPP, durasi video, kesesuaian penggunaan virtual reality dan
Gorga : Jurnal Seni Rupa

Volume 10 Nomor 02 Juli-Desember 2021 p-ISSN: 2301-5942 | e-ISSN: 2580-2380

kesesuaian dengan bahan ajar, maka dapat digunakan dengan predikat baik. Hal ini menjadi suatu dasar dalam pengembagan video media pembelajaran baik secara kreatif dan inovasi.

Berdasarkan hasil penilaian yang dilakukan oleh validator maka indokator keseuaian kurikulum 2013, dengan 3 responden maka score total 11, score maxsimal 12, persentasi $91,6 \%$ dinyatkan sangat baik, sedangkan kesesuaian silabus dan RPP score total 12, score maxsimal 12, persentasi $100 \%$ dapat diyatakan sangat baik. Kesesuaian durasi video dengan score total 10 , score maxsimal 12 , persentasi 83,3 , diyatakan sangat baik, dan kesesuaian penggunaan virtual reality, score totalnya 12 , score maxsimal 12 , persentasi $100 \%$, dengan capaian sangat baik. Kesesuaian perangkat mengajar dan bahan ajar, score total 11, score maxsimal 12, persentasi $91,6 \%$ dapat diyatakan sangat baik. Berdasarkan penilaian yang dilakukan maka dapat di lanjutkan karena sudah sesuai dengan capaian setiap aspek.

Tabel 5. Persentasi Hasil Validasi Proses Kegiatan Pembelajaran pada Produk Video Media Pembelajaran Seni Rupa Tradisional Suku Dayak di Kalimantan Tengah Berbasis Virtual Reality di SMPN 02 Palangka Raya (Zunaidah, 2016:23)

\begin{tabular}{|c|c|c|c|c|c|}
\hline \multirow[t]{2}{*}{ No } & $\begin{array}{c}\text { Aspek } \\
\text { Validasi }\end{array}$ & \multirow{2}{*}{$\begin{array}{c}\text { Score } \\
\text { total } \\
\text { untuk } \\
3 \\
\text { Respo } \\
\text { nden }\end{array}$} & \multirow{2}{*}{$\begin{array}{c}\text { Skor } \\
\text { max } \\
\text { untuk } \\
3 \\
\text { Respo } \\
\text { nden }\end{array}$} & \multirow[t]{2}{*}{$\%$} & \multirow{2}{*}{$\begin{array}{c}\text { Kriter } \\
\text { ia } \\
\text { penila } \\
\text { ian } \\
\text { produ } \\
\mathbf{k}\end{array}$} \\
\hline & $\begin{array}{c}\text { Proses } \\
\text { kegiatan/ke } \\
\text { giatan } \\
\text { pembelajar } \\
\text { an }\end{array}$ & & & & \\
\hline 1 & $\begin{array}{l}\text { Kesesuaian } \\
\text { isi gambar } \\
\text { dan video }\end{array}$ & 10 & 12 & 83,3 & $\begin{array}{c}\text { Sangat } \\
\text { Baik }\end{array}$ \\
\hline 2 & $\begin{array}{l}\text { Kesesuaian } \\
\text { audio } \\
\text { visual. }\end{array}$ & 12 & 12 & 100 & $\begin{array}{c}\text { Sangat } \\
\text { Baik }\end{array}$ \\
\hline 3 & $\begin{array}{l}\text { Penyampaia } \\
\mathrm{n} \\
\text { pembelajara } \\
\mathrm{n} \text { menjadi } \\
\text { jelas }\end{array}$ & 11 & 12 & 91,6 & $\begin{array}{c}\text { Sangat } \\
\text { Baik }\end{array}$ \\
\hline 4 & $\begin{array}{l}\text { Pengaruh } \\
\text { terhadap } \\
\text { sikap }\end{array}$ & 10 & 12 & 83,3 & $\begin{array}{c}\text { Sangat } \\
\text { Baik }\end{array}$ \\
\hline 5 & $\begin{array}{l}\text { Pengaruh } \\
\text { terhadap } \\
\text { pengetahua } \\
\mathrm{n}\end{array}$ & 12 & 12 & 100 & $\begin{array}{c}\text { Sangat } \\
\text { Baik }\end{array}$ \\
\hline 6 & $\begin{array}{l}\text { Pengaruh } \\
\text { pada } \\
\text { keterampila } \\
\mathrm{n}\end{array}$ & 11 & 12 & 91,6 & $\begin{array}{c}\text { Sangat } \\
\text { Baik }\end{array}$ \\
\hline 7 & $\begin{array}{l}\text { Strategi } \\
\text { pembelajara } \\
\text { n yang } \\
\text { digunakan } \\
\text { sesuai. }\end{array}$ & 12 & 12 & 100 & $\begin{array}{c}\text { Sangat } \\
\text { Baik }\end{array}$ \\
\hline 8 & $\begin{array}{l}\text { Proses } \\
\text { evaluasi } \\
\text { pembelajara } \\
\text { n dapat } \\
\text { dilaksanaka } \\
\text { n. }\end{array}$ & 11 & 12 & 91,6 & $\begin{array}{c}\text { Sangat } \\
\text { Baik }\end{array}$ \\
\hline
\end{tabular}


Gorga : Jurnal Seni Rupa

Volume 10 Nomor 02 Juli-Desember 2021 p-ISSN: 2301-5942 | e-ISSN: 2580-2380

Berdasarkan hasil dari hasil tabel penilaian yang dilakukan oleh validator maka setiap aspek, khususnya dalam kegiatan pembelajaran yang meliputi kesesuaian isi gambar dan video dengan 3 responden maka score total yang didapatkan 10, score maxsimal 12, persentasi 83,3, dapat dinyatakan sangat baik, sedangkan kesesuaian audio visual, score total 12, score maxsimal 12, persentasi $100 \%$, kriteria penilaian sangat baik. Indikator pada bagian penyampaian pembelajaran menjadi jelas, dengan score 11 , score maxsimal 12, persentasi $91,6 \%$, sangat baik, dan pengaruh terhadap sikap meliputi score total 10, score maxsimal 12, persentasi 83,3, sangat baik.

Pengaruh terhadap pengetahuan, dengan score total 12, score maxsimal 12, persentasi $100 \%$, diyatkan sangat baik, sedangkan pengaruh pada keterampilan, score total 11, score maxsimal 12, persentasi $91,6 \%$, sangat baik. Dalam penilaian strategi pembelajaran yang digunakan, score total 12 , score maxsimal 12 , persentasi $100 \%$, sangat baik, dan kegiatan proses evaluasi embelajaran yang dilaksanakan, dengan score total 11, score maxsimal 12, persentasi $91,6 \%$, dapat diyatakan sangat baik. Berdasarkan hasil penilaian yang dilakukan maka tahapan proses kegiatan pembelajaran pengembangan video media pembelajaran berbasis virtual reality, pada mata pelajaran seni rupa tradisional Dayak Kalimantan Tengah, di lingkungan SMPN 02 Palangka Raya, dapat di kembangkan dan digunakan, karena dianggap sudah sangat baik dan layak.

Tabel 6. Persentasi Hasil Validasi Penyajian Pembelajaran pada Produk Video Media Pembelajaran Seni Rupa Tradisional Suku Dayak di Kalimantan Tengah Berbasis Virtual Reality di SMPN 02

Palangka Raya

(Zunaidah, 2016:23)

\begin{tabular}{|c|c|c|c|c|c|}
\hline \multirow[t]{2}{*}{ No } & $\begin{array}{c}\text { Aspek } \\
\text { Validasi }\end{array}$ & $\begin{array}{c}\text { Score } \\
\text { total }\end{array}$ & $\begin{array}{c}\text { Skor } \\
\text { max }\end{array}$ & $\%$ & \multirow{2}{*}{$\begin{array}{c}\text { Kriteria } \\
\text { penilaia } \\
n \\
\text { produk }\end{array}$} \\
\hline & $\begin{array}{c}\text { Penyajia } \\
\text { n } \\
\text { Pembelaj } \\
\text { aran }\end{array}$ & $\begin{array}{c}\text { untuk } \\
3 \\
\text { Respo } \\
\text { nden }\end{array}$ & $\begin{array}{c}\text { untuk } \\
3 \\
\text { Respo } \\
\text { nden }\end{array}$ & & \\
\hline 1 & $\begin{array}{l}\text { Kesesuaia } \\
\mathrm{n} \text { materi } \\
\text { seni rupa } \\
\text { tradisional } \\
\text { suku } \\
\text { Dayak } \\
\text { Kalimanta } \\
\mathrm{n} \text { Tengah. }\end{array}$ & 12 & 12 & 100 & $\begin{array}{c}\text { Sangat } \\
\text { Baik }\end{array}$ \\
\hline 2 & $\begin{array}{l}\text { Kesesuaia } \\
\mathrm{n} \text { video } \\
\text { media } \\
\text { pembelaja } \\
\text { ran seni } \\
\text { rupa } \\
\text { tradisional } \\
\text { suku } \\
\text { Dayak, } \\
\text { berbasis }\end{array}$ & 11 & 12 & 91,6 & $\begin{array}{c}\text { Sangat } \\
\text { Baik }\end{array}$ \\
\hline
\end{tabular}

\begin{tabular}{|c|c|c|c|c|c|}
\hline & $\begin{array}{l}\text { virtual } \\
\text { reality. }\end{array}$ & & & & \\
\hline 3 & $\begin{array}{l}\text { Kesesuaia } \\
\mathrm{n} \text { evaluasi } \\
\text { pembelaja } \\
\text { ran seni } \\
\text { rupa } \\
\text { tradisional } \\
\text { suku } \\
\text { Dayak di } \\
\text { Kalimanta } \\
\text { n Tengah. }\end{array}$ & 12 & 12 & 100 & $\begin{array}{c}\text { Sangat } \\
\text { Baik }\end{array}$ \\
\hline
\end{tabular}

Berdasarkan dari isi dari tabel penilaian yang dilaksanakan oleh validator bidang media pembelajaran, maka aspek indikator penyajian pembelajaran dengan muatan kesesuaian materi seni rupa tradisional suku Dayak Kalimatan Tengah, dengan 3 responden maka total score 12 , score maxsimal 13, persentasi $100 \%$, sangat baik, dan kesesuaian video media pembelajaran seni rupa tradisional suku Dayak Berbasis virtual reality, dengan score total 11, score maxsimal 12, persentasi 91,6\%, sangat baik. Kesesuaian evaluasi pembelajaran seni rupa tradisional suku Dayak di Kalimantan Tengah, score total 12, score maxsimal 12, persentasi $100 \%$, sangat baik. Berdasarkan penilaian pada aspek penyajian pembelajaran mengunakan pengembangan video media pembelajaran berbasis virtual reality pada karya seni rupa tradisional masyarakat Dayak Kalimantan Tengah di SMPN 02 Palangka Raya, dapat di kembangkan dan di terapkan.

Tabel 7. Capaian Aspek Validasi Penyajian pada Produk Video Media Pembelajaran Seni Rupa Tradisional Suku Dayak di Kalimantan Tengah Berbasis Virtual Reality di SMPN 02 Palangka Raya

(Zunaidah, 2016:23)

\begin{tabular}{|c|c|c|c|c|c|}
\hline No & $\begin{array}{c}\text { Aspek } \\
\text { Validasi } \\
\text { Penyaji } \\
\text { an }\end{array}$ & $\begin{array}{c}\text { Score } \\
\text { total } \\
\text { untuk } \\
3 \\
\text { Respo } \\
\text { nden }\end{array}$ & $\begin{array}{c}\text { Skor } \\
\text { max } \\
\text { untuk } \\
3 \\
\text { Respo } \\
\text { nden }\end{array}$ & $\%$ & $\begin{array}{c}\text { Kriteri } \\
\text { a } \\
\text { penilai } \\
\text { an } \\
\text { produk }\end{array}$ \\
\hline 1 & $\begin{array}{l}\text { Umpan } \\
\text { balik } \\
\text { untuk } \\
\text { peneliti }\end{array}$ & 10 & 12 & 83,3 & $\begin{array}{c}\text { Sangat } \\
\text { Baik }\end{array}$ \\
\hline 2 & $\begin{array}{l}\text { Konsiste } \\
\text { nsi } \\
\text { pengemb } \\
\text { angan } \\
\text { video } \\
\text { media } \\
\text { pembelaj } \\
\text { aran } \\
\text { berbasis } \\
\text { virtual } \\
\text { reality. }\end{array}$ & 12 & 12 & 100 & $\begin{array}{c}\text { Sangat } \\
\text { Baik }\end{array}$ \\
\hline 3 & $\begin{array}{l}\text { Karya } \\
\text { yang } \\
\text { dihasilka } \\
\mathrm{n} \\
\text { merupak } \\
\text { an karya } \\
\text { orisinil }\end{array}$ & 12 & 12 & 100 & $\begin{array}{c}\text { Sangat } \\
\text { Baik }\end{array}$ \\
\hline
\end{tabular}




\begin{tabular}{|l|l|l|l|}
\hline $\begin{array}{l}\text { (bukan } \\
\text { plagiat) }\end{array}$ \\
\hline \hline
\end{tabular}

Berdasarkan capaian aspek validasi penyajian produk video media pembelajaran seni rupa tradisional Dayak Kalimantan Tengah berbasis virtual reality di lingkungan SMPN 02 Palangka Raya, meliputi umpan balik untuk peneliti, dengan 3 responden, mencapai score total 10 , score maxsimal 12, persentasi 83,3\%, dengan krieria penilaian produk sangat baik, sedangkan konsistensi pengembangan video media pembelajaran berbasis virtual reality, score total 12, score maxsimal 12, persentasi $100 \%$. Aspek validasi karya yang dihasilkan merupakan karya orisinil, score total 12, score maxsimal 12, $100 \%$, kriteria penilaian produk sangat baik. Berdasarkan hasil penilaian maka dapat dinyatakan bahwa produk ini dapat di produksi dan di terapkan.

Tabel 8. Penilaian Aspek Validasi Kebahasaan pada Produk Video Media Pembelajaran Seni Rupa Tradisional Suku Dayak di Kalimantan Tengah Berbasis Virtual Reality di SMPN 02 Palangka Raya

(Zunaidah, 2016:23)

\begin{tabular}{|c|c|c|c|c|c|}
\hline No & $\begin{array}{c}\text { Aspek } \\
\text { Validasi } \\
\begin{array}{c}\text { Kebahas } \\
\text { aan }\end{array}\end{array}$ & $\begin{array}{c}\text { Score } \\
\text { total } \\
\text { untuk } \\
3 \\
\text { Respo } \\
\text { nden }\end{array}$ & $\begin{array}{c}\text { Skor } \\
\text { max } \\
\text { untuk } \\
3 \\
\text { Respo } \\
\text { nden }\end{array}$ & $\%$ & $\begin{array}{c}\text { Kriteria } \\
\text { penilaia } \\
\text { n } \\
\text { produk }\end{array}$ \\
\hline 1 & $\begin{array}{l}\text { Kemamp } \\
\text { uan } \\
\text { menginsp } \\
\text { irasi } \\
\text { Peneliti. }\end{array}$ & 12 & 12 & 100 & $\begin{array}{c}\text { Sangat } \\
\text { Baik }\end{array}$ \\
\hline 2 & $\begin{array}{l}\text { Membuat } \\
\text { peneliti } \\
\text { untuk } \\
\text { berpikir } \\
\text { kreatif. }\end{array}$ & 12 & 12 & 100 & $\begin{array}{l}\text { Sangat } \\
\text { Baik }\end{array}$ \\
\hline 3 & $\begin{array}{l}\text { Kebakua } \\
\mathrm{n} \\
\text { pengguna } \\
\text { an istilah } \\
\text { pada } \\
\text { video } \\
\text { media } \\
\text { pembelaj } \\
\text { aran seni } \\
\text { rupa } \\
\text { tradisiona } \\
\text { 1 Dayak, } \\
\text { berbasis } \\
\text { virtual } \\
\text { reality. }\end{array}$ & 11 & 12 & 91,6 & $\begin{array}{l}\text { Sangat } \\
\text { Baik }\end{array}$ \\
\hline 4 & $\begin{array}{l}\text { Penjelasa } \\
\text { n dengan } \\
\text { pemakna } \\
\text { an dalam } \\
\text { setiap } \\
\text { penyajian } \\
\text { pada } \\
\text { video } \\
\text { media } \\
\text { pembelaj } \\
\text { aran } \\
\text { karya } \\
\text { seni rupa } \\
\text { tradisiona } \\
\text { 1 Dayak, } \\
\text { berbasis } \\
\end{array}$ & 12 & 12 & 100 & $\begin{array}{c}\text { Sangat } \\
\text { Baik }\end{array}$ \\
\hline
\end{tabular}

Gorga : Jurnal Seni Rupa

Volume 10 Nomor 02 Juli-Desember 2021 p-ISSN: 2301-5942 | e-ISSN: 2580-2380

\begin{tabular}{|c|c|c|c|c|c|}
\hline & $\begin{array}{l}\text { virtual } \\
\text { reality. }\end{array}$ & & & & \\
\hline 5 & $\begin{array}{l}\text { Keterhub } \\
\text { ungan isi } \\
\text { materi } \\
\text { dengan } \\
\text { video } \\
\text { media } \\
\text { pembelaj } \\
\text { aran seni } \\
\text { rupa } \\
\text { tradisiona } \\
\text { 1 suku } \\
\text { Dayak, } \\
\text { berbasis } \\
\text { virtual } \\
\text { reality. }\end{array}$ & 11 & 12 & 91,6 & $\begin{array}{c}\text { Sangat } \\
\text { Baik }\end{array}$ \\
\hline 6 & $\begin{array}{l}\text { Kebakua } \\
\mathrm{n} \\
\text { pengguna } \\
\mathrm{n} \text { bahasa } \\
\text { pada } \\
\text { video } \\
\text { media } \\
\text { pembelaj } \\
\text { aran seni } \\
\text { rupa } \\
\text { tradisiona } \\
\text { 1 Dayak, } \\
\text { berbasis } \\
\text { virtual } \\
\text { reality. }\end{array}$ & 11 & 12 & 91,6 & $\begin{array}{c}\text { Sangat } \\
\text { Baik }\end{array}$ \\
\hline
\end{tabular}

Penialaian aspek kebahasaan yang dilakukan oleh validator meliputi kemampuan menginspirasi peneliti, dengan melibatkan 3 resoponden, score total 12, score maxsimal 12, persentasi $100 \%$, sangat baik, sedangkan aspek membuat peneliti menjadi kreatif, score total 12, score maxsimal 12, persentasi $100 \%$, sangat baik. Kebakuan penggunaan istilah pada video media pembelajaran seni rupa tradisional Dayak, berbasis virtual reality, mencapai score total 11 , score maxsimal 12, persentasi 91,6\%, sangat baik, sedangkan penjelasan dengan pemaknaan dalam setiap penyajian pada video media pembelajaran karya seni rupa tradisional Dayak, berbasis virtual reality, score total 12 , score maxsimal 12 , persentasi $100 \%$, sangat baik.

Keterhubungan isi materi dengan video media pembelajaran seni rupa tradisional suku Dayak, berbasis virtual reality, mencapai score total 11, score maxsimal 12, persentasi $91,6 \%$, sangat baik, dan kebakuan penggunan bahasa pada video media pembelajaran seni rupa tradisional Dayak, berbasis virtual reality, score total 11, score maxsimal 12, persentasi $91,6 \%$, Sangat baik. Berdasarkan hasil penilaian maka dalam tahapan ini, dapat dinyatakan bahwa produk ini dinyatakan sangat baik dan layak untuk di kembangkan serta di produksi. 


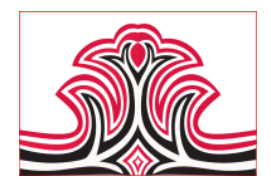

Tabel 9. Penilaian Aspek Validasi Penerapan pada Produk Video Media Pembelajaran Seni Rupa Tradisional Suku Dayak di Kalimantan Tengah Berbasis Virtual Reality di SMPN 02 Palangka Raya

(Zunaidah, 2016:23)

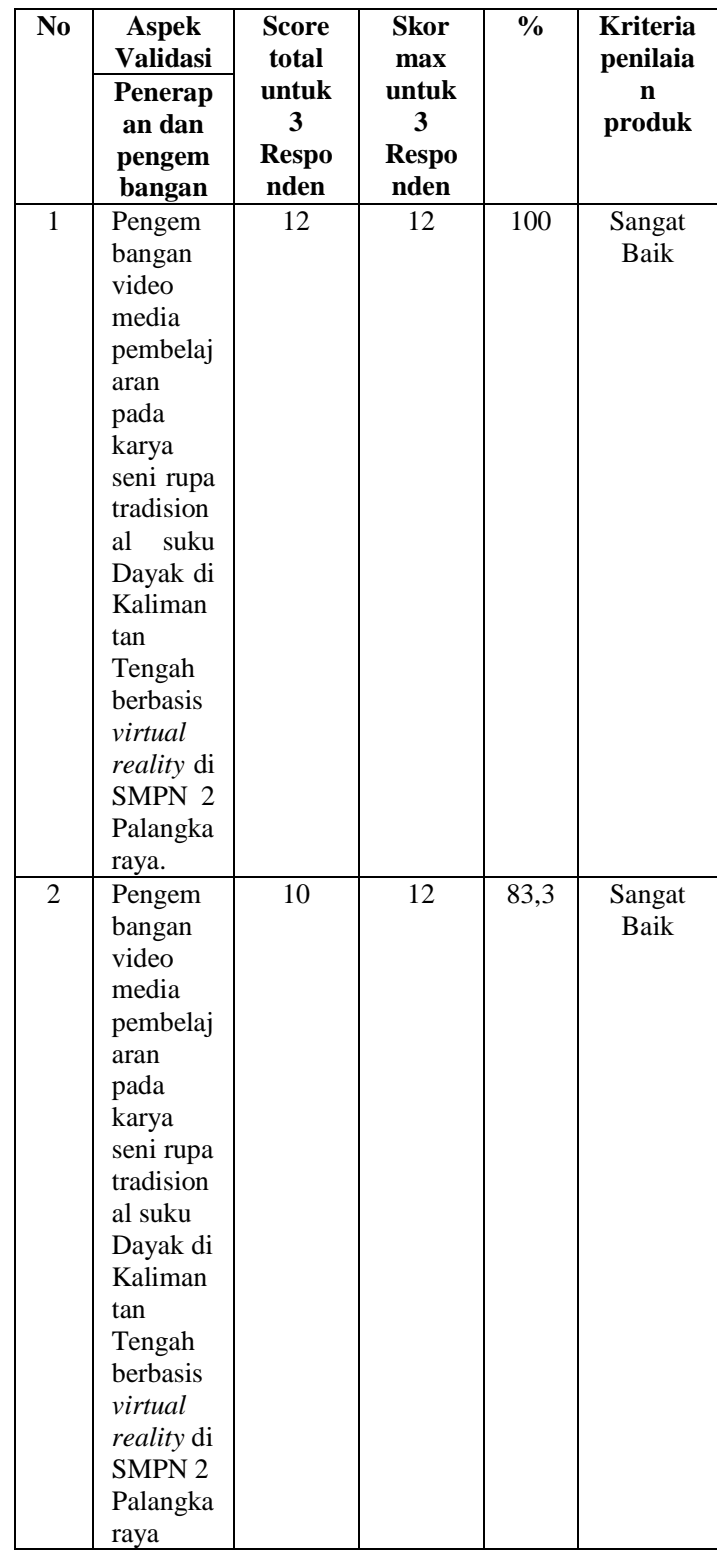

Penilaian yang dilaksanakan oleh validator berdasarkan penerapan pengembangan video media pembelajaran pada karya seni rupa tradisional suku Dayak di Kalimantan Tengah berbasis virtual reality di SMPN 2 Palangkaraya, dengan 3 responden, maka score total yang diperoleh 12, score maxsimal 12, persentasi 100\%, sangat baik, sedangkan pengembangan video media pembelajaran pada karya seni rupa tradisional suku Dayak di Kalimantan Tengah berbasis virtual reality di SMPN 2 Palangkaraya, score total 10 , score maxsimal 12 , dengan persentasi $83,3 \%$, sangat baik. Berdasarkan penilaian secara umum, maka hasil yang diperoleh sangat baik dan produk yang di buat dapat dikembangkan, produksi dan diterapkan.
Gorga : Jurnal Seni Rupa

Volume 10 Nomor 02 Juli-Desember 2021 p-ISSN: 2301-5942 | e-ISSN: 2580-2380

Berdasarkan dari penilaian yang dilakukan oleh validator secara keseluruhan, bahwa pengembangan video media pembelajaran seni rupa tradisional Dayak di Kalimantan Tengah berbasis virtual reality di SMPN 02 Palangka Raya, dapat di kembangkan lebih lanjut dengan pengembangan secara kreatif dan inovatif yang berkaitan dengan kebudayaan lokal secara virtual, sehingga dapat menjadikan kekhasan dalam mempublikasi cagar budaya dalam duni pendidikan. Pengembangan berikutnya berdasarkan saran validator, dapat mengembangkan pembuatan video dengan jenis kamera 360. Hal ini dengan tujuan agar karya yang diperoleh dapat memberikan efek audio visual yang lebih menarik. Produk yang di kembangkan ini dapat segera di produksi, dan diterapkan dalam dunia pendidikan.

\section{KESIMPULAN DAN SARAN}

\section{Kesimpulan}

Berdasarkan pengembangan produk video media pembelajaran seni rupa tradisional Dayak Kalimantan Tengah berbasis virtual reality di lingkungan SMPN 02 Palangka Raya, dapat menjadi sumber belajar dan layak di kembangkan, baik berupa konten,isi materi, serta adanya dukungan berupa kurikulum pendidikan seni budaya yang sesuai. Dalam mengembangkan video media pembelajaran berbasis virtual reality pada mata pelajaran seni rupa, di SMPN 02 Palangka Raya, membahas tema tentang seni kerajinan, arsitektur, patung, ragam hias, senjata tradisional, yang berkaitan dengan kebudayaan Dayak di Kalimantan Tengah. Hal ini di kemas dalam bentuk video dengan 2 bagian video berdasarkan durasi dan pertemuan pembelajaran. Video yang dikembangkan di peroleh dari studi lapangan dengan merekam dan foto, yang kemudian di kembangkan dalam bentuk proses editing menggunakan aplikasi VN pada android, sehingga menjadi suatu video media pembelajaran, kemudian produk ini telah di validasi oleh ahli media dan telah di ujicoba oleh pihak sekolah yaitu, siswa, guru mata pelajaran seni budaya, wakil kepala sekolah bidang kurikulum, kepala sekolah dan ahli media. Produk yang dikembangkan sangat efektif dalam penembangan media pembelajaran video berbasis virtual reality, dalam menigkatkan konsentrasi dan kejelasan objek pada video. Tujuan lainnya aktifitas pengembangan media pembelajaran ini dapat menigkatkan kemampuan siswa dalam menganalisis dan mengapresiasi seni dan budaya daerah Kalimantan Tengah, dengan memenuhi aspek sikap, pengetahuan dan keterampilan. 


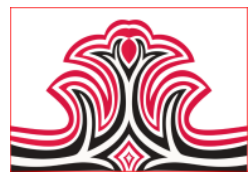

2. Saran

Kepada tokoh adat Dayak untuk terus menjaga nilainilai kebudayaan lokal melalui karya seni rupa yang dikembangkan melalui video media pembelajaran berbasis virtual reality. Hal itu dibuktikan dengan di muatnya kurikulum pendidikan secara formal yang menekankan kepada budaya lokal, khususnya budaya Dayak yang ada di Kalimantan Tengah, agar identitas budaya daerah dapat di lestarikan secara turun temurun, melalui dunia pendidikan.

Kepada pihak sekolah yang menjadi sasaran dalam pengembangan teknologi video media pembelajaran seni rupa berbasis virtual reality, dapat mengembangkan lagi dari produk-produk media yang sudah ada, sebagai dasar acuan dalam membuat media pembelajaran. Hal ini berkaitan dengan program pemerintah dalam mengembangkan percepatan pendidikan baik di bidang pengajaran dan media pembelajaran seni rupa. Kepada peserta didik dan guru mata pelajaran seni budaya dapat berkreasi lagi dalam pembelajaran, khususnya dalam pemanfaatan teknologi virtual reality.

\section{DAFTAR RUJUKAN}

Ardipal, A. (2012). Kurikulum Pendidikan Seni Budaya yang Ideal bagi Peserta Didik di Masa Depan. Komposisi: Jurnal Pendidikan Bahasa, Sastra, dan Seni, 11(1), 1-12.

Dewi, D. K. (2016). Pengaruh Tingkat Pendidikan dan Motivasi Kerja Terhadap Kinerja Karyawan. Journal Bisma, 4(1), 1-15.

Domingo, J. R., \& Bradley, E. G. (2018). Education student perceptions of virtual reality as a learning tool. Journal of Educational Technology Systems, 46(3), 329-342.

Fujiawati, F. S. (2016). Pemahaman konsep kurikulum dan pembelajaran dengan peta konsep bagi mahasiswa pendidikan seni. JPKS (Jurnal Pendidikan dan Kajian Seni), 1(1), 16-29.

Harianto, W. E. (2014). Penerapan Media Pembelajaran Seni Rupa Berbasis Audio Visual Pada materi Batik Siswa Kelas VIII-B dan VIII-C SMP Negeri 1 Turi Lamongan. Jurnal Pendidikan Seni Rupa, 2(3), 34-44.

Lase, D. (2019). Pendidikan di Era Revolusi Industri 4.0. Jurnal Sundermann, 1(2), 28-43.

Nurseto, T. (2011). Membuat Media Pembelajaran yang Menarik. Jurnal Ekonomi \& Pendidikan, $8(1), 20-31$.

Nusantara, T. (2018). Desain Pembelajaran 4.0. Prosiding Lembaga Penelitian Pendidikan (LPP) Mandala NTB. 1-16.
Gorga : Jurnal Seni Rupa

Volume 10 Nomor 02 Juli-Desember 2021 p-ISSN: 2301-5942 | e-ISSN: 2580-2380

Pranoto, Iwan. (2020). "Media Pembelajaran Seni Rupa”. Hasil Dokumentasi Pribadi: 01 Juni 2020, SMPN 2 Palangka Raya.

Ratnanigsih, K. (2020). Pengembangan Media Pembelajaran Seni Budaya Berbasis Digital Eksotisme Lukisan Pada Caping. Jurnal Ilmiah Kependidikan, 3(2), 62-74.

Retnanigsih, D. (2019). Tantangan Dan Strategi Guru Di Era Revolusi Industri 4.0 Dalam Meningkatkan Kualitas Pendidikan. Prosiding Seminar Nasional. 25-38.

Setiaji, R. S. (2020). Smartphone Media Berkarya Seni Masa Kini. Jurnal Imaji, 18(1), 14-26.

Sofa, T. M. (2020). Pembelajaran Seni Tari Dalam Menghadapi Tantangan Revolusi Industri 4.0. Jurnal Imaji, 18(1), 1-16.

Suhaya. (2016). Pendidikan Seni Sebagai Penunjang Kreatifitas".Jurnal Pendidikan dan Kajian Seni, 1(1), 1-14.

Sugiyono. (2011). Metode Penelitian Kuantitatif, Kualitatif dan $R \& D$. Bandung: Afabeta.

Suryani, L. (2021). Penerapan Media Audio Visual untuk Meningkatan Perilaku Cinta Lingkungan pada Golden Age. Jurnal Obsesi, 5(1), 902-917.

Trinawindu, I K. (2016). Multimedia Interaktif untuk Proses Pembelajaran. Jurnal Parabangkara, 19(23). 37-48.

Zunaidah. F. N. (2016). Pengembangan Bahan Ajar Mata Kuliah Bioteknologi Berdasarkan Kebutuhan Dan Karakter Kebutuhan dan Karakter Mahasiswa Universitas Nusantara PGRI Kediri. Jurnal Pendidikan Biologi Indonesia, 2(1), 19-30. 